\title{
Phenolic compounds of Dasiphora fruticosa plants from natural populations in the south of the Russian Far East
}

\author{
Elena $V$. Andysheva ${ }^{1 *}$, and Elena P. Khramova ${ }^{2}$ \\ ${ }^{1}$ Amur Branch of Botanical Garden-Institute FEB RAS, 675000 Ignatievskoye Road, 2nd km, \\ Blagoveshchensk, Russia \\ ${ }^{2}$ Central Siberian Botanical Garden SB RAS, 630090 Zolotodolinskaya Str., 101, Novosibirsk, Russia
}

\begin{abstract}
The profile and amounts were determined for phenolic compounds in the leaves of Dasiphora fruticosa plants growing in natural populations in the south of the Russian Far East. It was found that the phenolic profiles of the plants are similar among all the analyzed populations, but there are differences in the concentrations of the phenolic compounds. Total concentrations of phenolic compounds, flavonols, rhamnetin glycosides, and free quercetin are $12-46 \%$ higher in the leaves of plants of three populations from Shikotan Island. The highest total concentration of ellagic compounds $(12.6 \mathrm{mg} / \mathrm{g})$ was noted in the population from Primorsky Krai.
\end{abstract}

Potential usefulness of Dasiphora fruticosa (L.) Rydb. (三Pentaphylloides fruticosa (L.) O. Schwarz) from the family Rosaceae Juss. [1], when applied as a medicinal plant, has aroused much interest among pharmacologists, resource specialists, and innovation specialists. There is evidence of anti-inflammatory, hypoglycemic, antiallergic, immunomodulatory, antioxidant, antibacterial, analgesic, and antimicrobial properties of the plant material from $D$. fruticosa [2-8]. These broad-spectrum therapeutic activities result from the presence of phenolic compounds, mostly flavonols, which are largely responsible for the therapeutic effect of this plant material. The concentration of flavonols varies from $0.7 \%$ to $6.0 \%$, thus making the research on their profile and levels relevant and important. The phenolic profile of $D$. fruticosa has been studied in sufficient detail [9-12]. Nonetheless, the pattern and amounts of biochemical compounds in D. fruticosa plants growing on the territory of the Russian Far East are poorly studied, even though this species is widespread in this part of its areal.

The aim of this study was a comparative analysis of the profiles and levels of phenolic compounds in the leaves of $D$. fruticosa plants among populations growing in the south of the Russian Far East.

The biological material for the study consisted of specimens of $D$. fruticosa collected from four coenotic populations (CPs) in the south of the Russian Far East: from Primorsky Krai (CP 1) and from Shikotan Island of the Smaller Kuril Archipelago (CPs 2-4; Table 1). Meteorological parameters of the study sites are different. Primorsky Krai is characterized

${ }^{*}$ Corresponding author: lenok-luchik@mail.ru 
by a moderate monsoon climate with dry cold winter and warm humid summer. The average air temperature in January is $-12^{\circ} \mathrm{C}$ and in July $+17.5^{\circ} \mathrm{C}$; annual precipitation is $840 \mathrm{~mm} /$ year, and sunshine $1414 \mathrm{~h} /$ year [13]. Shikotan Island is characterized by a mild moderately marine climate affected by monsoons, with warm winter and mild summer; the high humidity does not have a negative effect because of the mild temperature regimen: the average air temperature in January is $-4.6^{\circ} \mathrm{C}$ and in July $+16.3^{\circ} \mathrm{C}$; annual precipitation is $894 \mathrm{~mm} /$ year, with sunshine at $1606 \mathrm{~h} /$ year [14].

Table 1. Sites of sampling of $D$. fruticosa specimens.

\begin{tabular}{|c|c|}
\hline Coenotic populations & Sampling site, habitat, coordinates \\
\hline CP 1: Ol'khovaya & $\begin{array}{l}\text { Primorsky Krai, Partizansky District, slope of mountain Ol'khovaya, } \\
43.20364^{\circ} \mathrm{N}, 133.39275^{\circ} \mathrm{E}, 1581 \mathrm{~m} \text { above sea level }\end{array}$ \\
\hline CP 2: Otradnaya & $\begin{array}{l}\text { Sakhalin Oblast, Yuzhno-Kurilsky District, northeastern coast of } \\
\text { Shikotan Island, Otradnaya Bay, } 43.52180^{\circ} \mathrm{N}, 146.47037^{\circ} \mathrm{E}, 54 \mathrm{~m} \\
\text { above sea level }\end{array}$ \\
\hline CP 3: Malokuril'skaya & $\begin{array}{l}\text { Sakhalin Oblast, Yuzhno-Kurilsky District, northeastern coast of } \\
\text { Shikotan Island, near Malokuril'skoe village, } 43.52531^{\circ} \mathrm{N} \text {, } \\
146.49215^{\circ} \mathrm{E}, 24 \mathrm{~m} \text { above sea level }\end{array}$ \\
\hline CP 4: Gorobetskaya & $\begin{array}{l}\text { Sakhalin Oblast, Yuzhno-Kurilsky District, northwestern coast of } \\
\text { Shikotan Island, Gorobets bay, } 43.4936^{\circ} \mathrm{N}, 146.4224^{\circ} \mathrm{E}, 55 \mathrm{~m} \text { above } \\
\text { sea level }\end{array}$ \\
\hline
\end{tabular}

To measure the concentrations of phenolic compounds, representative sampling was conducted involving 30 specimens from each population at the mass flowering stage. Yearold foliated shoots $15-20 \mathrm{~cm}$ long were cut down uniformly according to the crown surface, were separated into organs, and air-dried completely. Aqueous ethanolic extracts of the plant samples were prepared by a standard method [15]. To eliminate hydrophilic compounds, solid-phase extraction was performed [16]. A detailed description of the method for sample preparation is provided in a study by Khramova E.P. and colleagues [6]. The quantitation of phenolic compounds was carried out by high-performance liquid chromatography (HPLC) on an Agilent 1100 liquid chromatograph (Agilent Technologies, USA) equipped with a UV spectrophotometric detector and the ChemStation software for chromatographic-data analysis, according to a modified T.A. van Beek procedure [17], at the Central Siberian Botanical Garden SB RAS [18]. All the data were normalized to absolutely dry weight of the starting plant material. Because standard samples were unavailable for the quantitation of flavonol glycosides in D. fruticosa leaf extracts by HPLC, we analyzed free aglycons forming after acid hydrolysis of respective glycosides, with subsequent conversion of the data to the amounts of flavonol glycosides [17, 19].

The results showed that the leaf extracts from the plants contain at least 21 phenolic compounds. Ten compounds were identified, among them, six flavonol glycosides (hyperoside, isoquercitrin, avicularin, quercitrin, astragalin, and kaempferol-3-Orutinoside), two aglycons (quercetin and kaempferol), and two ellagic tannins (ellagic acid and its glycoside). According to the UV spectra recorded in on-line mode, the other phenolic components (ID numbers 1-3, 9, 13, 15-19) were assigned flavonoid structures (Table 2).

It was found that the phenolic profiles of $D$. fruticosa leaves are similar among the populations being studied. In the leaf samples from all the analyzed populations, we detected hyperoside, isoquercitrin, ellagic acid and its glycoside, avicularin, astragalin, kaempferol-3-O-rutinoside, and quercetin. Additionally, in the samples from population Ol'khovaya (CP 1), quercitrin was present as a minor phenolic component, and the same was true for kaempferol in the samples from population Gorobetskaya (CP 4). 
Quantitative differences in the accumulation of phenolic compounds were observed too. For instance, the highest concentration of hyperoside $(5.10 \mathrm{mg} / \mathrm{g})$ was detected in the leaves of plants from population Ol'khovaya (CP 1); the highest concentrations of isoquercitrin $(3.84 \mathrm{mg} / \mathrm{g})$, avicularin $(4.10 \mathrm{mg} / \mathrm{g})$, kaempferol-3-O-rutinoside $(0.45 \mathrm{mg} / \mathrm{g})$, and quercetin $(0.21 \mathrm{mg} / \mathrm{g})$ were registered in the leaves of plants from population Otradnaya (CP 2); and the highest concentration of astragalin $(0.37 \mathrm{mg} / \mathrm{g})$ was found in the leaves of plants from population Malokuril'skaya (CP 3; Table 2).

Table 2. Concentrations of phenolic compounds in the leaves of $D$. fruticosa ( $\mathrm{mg} / \mathrm{g}$ of absolutely dry weight).

\begin{tabular}{|c|c|c|c|c|}
\hline \multirow[t]{3}{*}{ Phenolic compounds } & \multicolumn{4}{|c|}{ Coenotic populations } \\
\hline & \multirow{2}{*}{$\begin{array}{c}\text { Primorsky Krai } \\
\text { Ol'khovaya, } \\
\text { CP 1 }\end{array}$} & \multicolumn{3}{|c|}{ Shikotan Island } \\
\hline & & $\begin{array}{l}\text { Otradnaya, } \\
\text { CP } 2\end{array}$ & $\begin{array}{c}\text { Malokuril'skaya, CP } \\
3\end{array}$ & $\begin{array}{c}\text { Gorobetskaya, } \\
\text { CP } 4\end{array}$ \\
\hline \multicolumn{5}{|c|}{ In aqueous ethanol extracts: } \\
\hline Compound 1 & 1.67 & $-{ }^{1}$ & - & - \\
\hline Compound 2 & 3.69 & 0.40 & 0.91 & 0.14 \\
\hline Compound 3 & 0.42 & - & - & 0.20 \\
\hline Hyperoside & 5.10 & 2.16 & 0.85 & 0.48 \\
\hline Isoquercitrin & 2.19 & 3.84 & 2.83 & 1.20 \\
\hline Ellagic acid & 5.97 & 2.92 & 0.16 & 0.29 \\
\hline Ellagic acid glycoside & 6.63 & 7.78 & 10.14 & 9.91 \\
\hline Avicularin & 0.23 & 4.10 & 3.40 & 3.14 \\
\hline Compound 9 & 0.18 & 4.94 & 5.28 & 2.32 \\
\hline Quercitrin & 0.05 & - & - & - \\
\hline Astragalin & 0.31 & 0.29 & 0.37 & 0.25 \\
\hline $\begin{array}{l}\text { Kaempferol-3-O- } \\
\text { rutinoside }\end{array}$ & 0.32 & 0.45 & 0.19 & 0.38 \\
\hline Compound 13 & - & 0.18 & - & - \\
\hline Quercetin & 0.13 & 0.21 & 0.19 & 0.06 \\
\hline Compound 15 & - & - & - & 0.14 \\
\hline Compound 16 & - & 0.12 & - & - \\
\hline Compound 17 & 0.26 & 0.99 & 1.28 & 1.29 \\
\hline Compound 18 & 0.16 & 0.15 & - & - \\
\hline Compound 19 & - & 0.49 & 0.42 & 0.35 \\
\hline Kaempferol & - & - & - & 0.06 \\
\hline Compound 21 & - & 2.19 & 4.94 & 7.70 \\
\hline $\begin{array}{l}\text { Total content of } \\
\text { phenolic compounds }\end{array}$ & 27.3 & 31.6 & 31.0 & 27.9 \\
\hline Sum of tannins & 12.6 & 10.70 & 10.30 & 10.20 \\
\hline \multicolumn{5}{|l|}{ In hydrolysates: } \\
\hline Sum of flavonols ${ }^{2}$ & 12.1 & 22.44 & 15.16 & 15.25 \\
\hline \multicolumn{5}{|l|}{ Including glycosides: } \\
\hline quercetin & 11.3 & 18.4 & 10.3 & 9.5 \\
\hline kaempferol & 0.71 & 1.09 & 0.64 & 0.60 \\
\hline rhamnetin & - & 2.69 & 4.04 & 5.02 \\
\hline
\end{tabular}

Notes: ${ }^{1}$ concentration below the detection limit $(0.1 \mathrm{mg} / \mathrm{g}),{ }^{2}$ total concentration of flavonols is a sum of concentrations of flavonol glycosides and free aglycons after acid hydrolysis.

The total concentrations of phenolic compounds in the leaves were almost identical among the studied populations, and the highest level $(31.6 \mathrm{mg} / \mathrm{g})$ was detected in the 
specimens from population Otradnaya on Shikotan Island (CP 3), whereas the lowest (27.3 $\mathrm{mg} / \mathrm{g}$ ) in population Ol'khovaya from Primorsky Krai (CP 1).

To analyze the concentrations of flavonol glycosides individually, we performed acid hydrolysis of the aqueous ethanolic extracts from $D$. fruticosa leaves.

The results showed that the total concentration of flavonols (consisting of a sum of flavonol glycosides and free aglycons after the acid hydrolysis) in the leaves of plants from population Otradnaya (CP 2) was 32-46\% higher as compared with the other populations and was $22.4 \mathrm{mg} / \mathrm{g}$, with the lowest level found in population Ol'khovaya (CP 1): 12.1 $\mathrm{mg} / \mathrm{g}$.

The differences among the plants from different habitats also manifested themselves in unequal proportions of aglycons in the leaf hydrolysates (Table 3). According to the analysis of aglycons that formed after the acid hydrolysis of $D$. fruticosa leaf extracts, three aglycons were identified in the hydrolysates: quercetin, kaempferol, and rhamnetin. Glycosides of quercetin and kaempferol were present in all the hydrolysates, whereas rhamnetin glycosides were undetectable in the leaf extract hydrolysates from population Ol'khovaya (CP 1, Primorsky Krai), where we noticed the highest concentration of quercetin glycosides: $95 \%$. All the studied populations of $D$. fruticosa contain quercetin glycosides, and in the leaves of plant populations Malokuril'skaya (CP 3) and Gorobetskaya (CP 4), aside from the dominant levels of quercetin derivatives (69\% and 63\%), there were substantial amounts of rhamnetin glycosides: $26 \%$ and $33 \%$, respectively. Concentrations of kaempferol glycosides proved to be nearly equal among the populations: $4 \%$ to $5 \%$ (Table 3).

The highest concentrations of glycosides of quercetin $(18.4 \mathrm{mg} / \mathrm{g})$ and of kaempferol $(1.09 \mathrm{mg} / \mathrm{g})$ were detected in the leaves of plant population Otradnaya (CP 2), i.e., 1.5-2.0fold higher than that in the other populations. By contrast, the concentration of rhamnetin was higher in two populations: Malokuril'skaya (CP 3) and Gorobetskaya (CP 4) from Shikotan Island (4.04 and $5.02 \mathrm{mg} / \mathrm{g}$, respectively; Table 2).

Table 3. The quercetin:kaempferol:rhamnetin ratio (\%) in the leaf extract hydrolysates from $D$. fruticosa.

\begin{tabular}{|c|c|c|c|}
\hline Ol'khovaya & Otradnaya & Malokuril'skaya & Gorobetskaya \\
\hline $95: 5: 0$ & $83: 5: 12$ & $69: 4: 26$ & $63: 5: 33$ \\
\hline
\end{tabular}

Among the studied populations, there were also differences in the accumulation of ellagic tannins (total and individual tannins). For example, the total concentration of ellagic compounds in the D. fruticosa leaves from population Ol'khovaya (CP 1) $(12.6 \mathrm{mg} / \mathrm{g})$ was 1.2-fold higher than that in the three Shikotan Island populations, among which, the total levels of ellagic compounds were roughly the same $(10.20-10.70 \mathrm{mg} / \mathrm{g})$. The highest concentration of ellagic acid was registered in D. fruticosa leaves from population Ol'khovaya (CP 1): $5.97 \mathrm{mg} / \mathrm{g}$. This is 2- to 37-fold higher relative to the three Kuril populations from Shikotan Island. In the plants of the Kuril populations, the concentration of a glycoside of ellagic acid turned out to be 1.1-1.5-fold higher than that in the samples from population Ol'khovaya (CP 1, Primorsky Krai; Table 2).

Thus, our results indicate that leaf phenolic profiles of $D$. fruticosa are similar among the four habitats and are represented by 21 compounds, but there are differences in the concentrations of the phenolic compounds. Six flavonol glycosides, two aglycons, and two ellagic tannins were identified. The highest total concentrations of phenolic compounds and of flavonols were revealed in the specimens of $D$. fruticosa present on Shikotan Island: population Otradnaya (CP 2) and Malokuril'skaya (CP 3). The highest total concentration of ellagic compounds was noted in the plants from population Ol'khovaya (CP 1, Primorsky Krai). These findings may be explained by differences in habitat conditions. Our study 
shows that quercetin glycosides are dominant in leaf samples from all four analyzed populations in the south of the Russian Far East.

The study was conducted within the framework of a state assignment titled "Evaluation of the modern biological diversity and resource potential of the East Asian flora" (AAAA-A17-117021310193-7). The English language was corrected and certified by shevchuk-editing.com.

\section{References}

1 K.S. Baikov, Check-list of flora of Asian Russia: Vascular plants, (Novosibirsk: Izd-vo SO RAN, 2012)

2 M.M. Ar'yaeva, T.A. Azhunova, S.M. Nikolaev, Rast. resursy 35, 97 (1999)

3 A.L. Budantsev, E.E. Lesiovskaya, Wild useful plants of Russia, (Saint-Peterburg: Izdvo SPKHA, 2001)

4 M. Tomczyk, M. Pleszczynska, A. Wiater, Molecules 15, 4651 (2010)

5 G. Miliauskas, T.A. van Beek, P.R. Venskutonis, J.P. Linssen, P. Waard, E.J. Sudhölter, J. Sci. Food and Agric. 84, 2009 (2009)

6 E.P. Khramova, N.V. Tsybulya, L.N. Chindyaeva, Rast. resursy 3, 611 (2013)

7 S. Wang, D. Wang, W. Pu, D. Li, BMC Compl. \& al. medicine. 13, 321 (2013)

8 D. Yu, W. Pu, D. Li, D. Wang, Q. Liu, Y. Wang, Chem. Biodiversity 13, 1148 (2016)

9 I.G. Nikolaeva, V.B. Khobrakova, M.M. Ar'yaeva, Pentaphylloides fruticosa (Dasiphora fruticosa), (Ulan-Ude: Izd-vo BNTS SO RAN, 2001)

10 S.Ya. Syeva, E.P. Khramovaa, O.V. Dorogina, Pentaphylloides of the Altai Mountain, (Novosibirsk, 2013)

11 E.P. Khramova, Rast. resursy 50, 135 (2014)

12 E.P. Khramova, The genus Pentaphylloides Hill (Rosaceae) of Asian Russia (phenolic compounds, element composition in the nature and culture, a chemotaxonomy): Dis. ... Doct. Biol. Sciences, (Novosibirsk, 2016)

13 Scientific-applied reference on the climate of the USSR. Issue 26. Part 1. Primorsky Krai, (Leningrad, Gidrometeoizdat., 1966)

14 Scientific-applied reference on the climate of the USSR. Series 3. Issue 34. Parts 1-6. Sakhalin Oblast, (Leningrad, Gidrometeoizdat., 1990)

15 A.I. Ermakov, V.V. Arasimovich, N.P. Yarosh, Biochemical methods of research of plants, (L., 1987)

16 K.S. Sychev, The methods of a high-performance liquid chromatography and a solidphase extraction, (M., 2005)

17 T.A. van Beek, J. of chromatography A., 967, 35 (2002)

18 E.P. Khramova, Himiya rast. syr'ya, 1, (2014)

19 D.V. Yur'ev, K.I. Eller, A.P. Arzamastsev, Farmatsiya, 2, 10 (2003) 